WMJ (Warmadewa Medical Journal), Vol.2, No.2, November 2017, Hal. 52-59

\title{
Optimalisasi Peran Fasilitator untuk Meningkatkan Keefektifan Diskusi Kelompok pada Blok Musculoskeletal System and Disorders
}

\author{
Asri Lestarini ${ }^{1}$, Sang Nyoman Suriana ${ }^{2}$ \\ ${ }^{1}$ Bagian Biokimia Fakultas Kedokteran dan Ilmu Kesehatan Universitas Warmadewa, Jl. Terompong, no 24, \\ Denpasar, Bali, Indonesia \\ ${ }^{2}$ Staff Medis Fungsional Rumah Sakit Umum Daerah, Gianyar \\ Email: asrilestarini@gmail.com
}

\begin{abstract}
Abstrak
Pelatihan fasilitator merupakan salah satu metode untuk mengoptimalkan peran fasilitator dalam diskusi kelompok sehingga terjadi peningkatan keefektifan diskusi. Penelitian ini mengevaluasi efektifitas diskusi kelompok dan motivasi intrinsik mahasiswa akibat pengaruh dari optimalisasi peran fasilitator pada blok Musculoskeleal System and Disorders. Pelatihan fasilitator dilakukan pada pertengahan blok dengan 5 peserta (fasilitator) yang merupakan fasilitator pada blok. Setiap kali diskusi pada blok (10 kali) baik sebelum dan sesudah pelatihan, mahasiswa (55 orang) diberikan kuisioner yang menggambarkan perilaku fasilitator, keefektifan diskusi kelompok dan motivasi intrinsik dari mahasiswa. Data kuisioner dianalisis dengan Cohens'd dan korelasi Pearson. Keefektifan diskusi kelompok secara umum yang dilihat dari rerata sebesar 3,88 setelah pelatihan, sedangkan 3,69 sebelum pelatihan menunjukkan adanya peningkatan ke arah positif daripada negatif tetapi perbedaan ini tidak bermakna secara praktis (Cohen's $d 0,93$ ). Rerata perilaku fasilitator selama diskusi sebesar 3,89 setelah pelatihan, sedangkan 3,81 sebelum pelatihan juga menunjukkan perbedaan yang tidak bermakna secara praktis (Cohen's $d$ 0,29). Hal ini juga terlihat pada motivasi intrinsik mahasiswa sebesar 5,08 setelah pelatihan, sedangkan 4,93 sebelum pelatihan (Cohen's $d 0,39$ ). Uji korelasi menunjukan hubungan peran fasilitator terhadap efektivitas diskusi kelompok $(0,325)$ setara bila dibandingkan dengan motivasi intrinsik mahasiswa (0,373). Pelatihan fasilitator pada blok Musculoskeletal System and Disorders menunjukkan arah yang positif tetapi tidak memiliki kemaknaan secara praktis sehingga masih banyak yang perlu ditingkatkan. Hubungan peran fasilitator terhadap efektifitas diskusi kelompok setara bila dibandingkan dengan motivasi intrinsik mahasiswa.
\end{abstract}

Kata Kunci: keefektifan diskusi kelompok, perilaku fasilitator, motivasi intrinsik mahasiswa

\section{Abstract}

\section{[Optimization Of Facilitator Role To Improve The Effectiveness Of Group Discussion On The Block Musculoskeletal System And Disorders]}

The facilitator training is one of methods to optimize the role of facilitator in group discussions in order to increase the effectiveness of the discussion. The aim of the research was to evaluate the effectiveness of group discussions and student intrinsic motivation due to the effect of optimizing the role of facilitator in the block Musculoskeletal System and Disorders. The facilitator training was carried out in middle of the block with 5 participants (facilitators) who were as tutor on the block. Each block discussion (10 times) both before and after the training, the students (55 people) were given a questionnaire comprise description of the facilitator behavior, the effectiveness of group discussion and intrinsic motivation of the students. Questionnaire data were analyzed with the Cohens'd and Pearson correlation. The effectiveness of group discussion in general was indicated by mean value which was slightly increased from 3.69 to 3.88 after training, it showed a positive effect although was not significant in practice (Cohen 's $d 0.93$ ). While, the mean value of the facilitator behavior during the discussions was slightly increased from 3.81 to 3.89 after training, also with no significant difference in practice (Cohen 's $d$ 0.29). In addition, the intrinsic motivation of students was also increased from 4.93 to 5.08 after training(Cohen 's d 0.39). Pearson correlation test showed the effectiveness of the facilitator role and discussion group (0.325) had an equal relationship compared to the intrinsic motivation of students (0.373). The training of facilitators on the block Musculoskeletal System 
and Disorders showed a positive effect although it was not practically significant. Therefore, improvement in some aspects are still required.

Keywords: Effectiveness of group discussion, the behavior of the facilitator, student intrinsic motivation.

\section{PENDAHULUAN}

Ilmu kedokteran merupakan bidang ilmu terapan sehingga pengetahuan yang kompleks digunakan untuk memecahkan satu masalah yang sama. Masalah di kedokteran menggunakan proses berpikir yang lebih luas yaitu rasional dan obyektif. Proses berpikir rasional dan obyektif dikenal dengan istilah berpikir kritis. Berpikir kritis merupakan kunci utama keberhasilan dalam menyelesaikan masalah klinis sebagai prerequisite dari kompetensi clinical reasoning. ${ }^{[1,2]}$ Untuk dapat menerapkan proses berfikir kritis ini pada mahasiswa dapat melalui strategi pembelajaran problem-based learning (PBL). Strategi pembelajaran ini menitikberatkan pembelajaran pada mahasiswa atau terpusat pada mahasiswa (student centered learning. ${ }^{[3]}$

Problem based learning (PBL) adalah salah satu pendekatan pembelajaran yang menggunakan masalah sebagai pemicu pembelajaran. Masalah yang diberikan bisa berupa masalah di klinik khususnya masalah-masalah yang sering terjadi maupun masalah di lapangan yang terkait dengan pokok bahasan yang akan didiskusikan oleh mahasiswa. ${ }^{[3,4]}$ Kelompok dalam PBL adalah kelompok diskusi kecil (small group discussion (SGD) yang terdiri dari 10-12 orang, difasilitasi oleh seorang dosen fasilitator. Masalah yang digunakan sebagai pencetus diskusi adalah fenomena atau kejadiankejadian sekitar. $^{[5]}$

Faktor-faktor yang mempengaruhi proses pembelajaran PBL diantaranya adalah faktor mahasiswa, dosen, fasilitas, proses pembelajaran, isi pembelajaran dan penjadwalan. $^{[4,6]}$ Peran fasilitator dalam PBL adalah memgidentifikasi kemampuan mahasiswa, membuat tantangan, menjadi model, mengaktifkan mahasiswa, memonitor perkembangan mahasiswa dan mengevaluasi hasil pembelajaran. ${ }^{[3,6]} \mathrm{Hal}$ ini menyebabkan kinerja fasilitator merupakan salah satu penentu keefektifan diskusi kelompok. $^{[7]}$

\section{METODE}

Metode yang dipakai adalah quasi eksperimental dengan desain pre eksperimental one group pretest-post-test. Subjek yang dilibatkan dalam proses pembelajaran blok Musculoskeletal System and Disorder adalah mahasiswa semester IV angkatan 2012, tahun ajaran 2013/2014 yang berjumlah 55 orang yang terbagi ke dalam 5 kelompok diskusi (SGD). Blok ini berlangsung selama 4 minggu.

Pelatihan fasilitator dilakukan pada minggu kedua (pertengahan blok) dengan 5 peserta (fasilitator) yang merupakan fasilitator pada blok. Pelatihan berupa pemaparan prinsip fasilitator dan simulasi di ruang diskusi.

Setiap kali diskusi pada blok (10 kali) baik sebelum dan sesudah pelatihan, mahasiswa diberikan kuisioner yang menggambarkan perilaku fasilitator, keefektifan diskusi kelompok dan motivasi intrinsik dari mahasiswa. Terdapat 3 jenis kuisioner yang dipakai yaitu Tutorial Group Effectiveness Instrument (TGEI), Tutor Behaviour Questionnare (TBQ) dan Intrinsic Motivation Inventory (IMI). TGEI memiliki 20 pertanyaan dengan skala 1-5 yang mengandung 3 aspek penilaian yaitu aspek kognitif, motivasi dan demotivasi. TBQ memiliki 10 pertanyaan dengan skala 1-5 yang mencakup 3 aspek berupa keselarasan peran, keselarasan kognitif dan penguasaan materi. IMI memiliki 20 pertanyaan dengan skala 1-7 yang mencakup 4 aspek yaitu ketertarikan, usaha, nilai dan ketegangan.

Salah satu metode analisis effect size adalah Cohen's $d$ yang akan dipakai dalam analisis data penelitian. Panduan dalam menilai Cohen's $d$ adalah sebagai berikut: $0-0.20$ (weak effect), $0.21-0.50$ (modest effect), $0.51-1.00$ (moderate effect), dan 1 (strong effect). Untuk perbedaan yang 
bermakna secara praktis dalam penelitian ini, peneliti menetapkan nilai Cohen's d > 1. Untuk melihat hubungan antara variabel perilaku fasilitator dengan efektivitas diskusi kelompok, motivasi intrinsik peneliti menggunakan kemaknaan praktis, dimana 0-0,299 (weak), 0,3-0,499 (moderate), 0,5-0,8 (strong), >0,8 (very strong). Peneliti menggunakan perangkat lunak IBM SPSS ver. 16 untuk menghitung korelasi antar berbagai variabel penelitian.

\section{HASIL}

Pengaruh optimalisasi peran fasilitator terhadap keefektifan diskusi kelompok

Sebanyak 550 kuisioner yang disebar, didapatkan sejumlah 26 kuisioner kosong, sehingga response rate sebesar 95,27\%. Pengisian kuisioner dilakukan sebelum pelatihan (pre) dan setelah pelatihan (post) untuk membandingkan serta melihat efek pelatihan fasilitator tersebut terhadap keefektifan diskusi kelompok. Kuisioner yang dipakai memiliki 20 pertanyaan yang mencakup 3 aspek, yaitu aspek kognitif, motivasi dan demotivasi.

Dapat dilihat pada Tabel 1, keefektifan diskusi kelompok secara umum yang dilihat dari rata-rata total sebesar 3,88 setelah pelatihan, sedangkan 3,69 sebelum pelatihan menunjukkan perbedaan yang tidak bermakna secara praktis antara kelompok sebelum pelatihan dan kelompok sesudah pelatihan berdasarkan dari analisis Cohen's $d$. Aspek yang dianalisis pada keefektifan diskusi kelompok yaitu aspek demotivasi menunjukkan perbedaan yang bermakna secara praktis dan memiliki efek yang kuat, sedangkan aspek kognitif dan aspek motivasi tidak menunjukkan perbedaan yang bermakna secara praktis. Tanda negatif (-) pada Cohen's $d$ menandakan nilai rerata kelompok pre pelatihan lebih tinggi dibandingkan dengan kelompok post perlakuan dan sebaliknya.

\section{Pengaruh optimalisasi peran fasilitator terhadap perilaku fasilitator dalam memfasilitasi diskusi kelompok}

Perilaku fasilitator selama diskusi tampak pada Tabel 2, secara umum yang dilihat dari rata-rata total sebesar 3,89 setelah pelatihan, sedangkan 3,81 sebelum pelatihan menunjukkan perbedaan yang tidak bermakna secara praktis antara kelompok perlakuan dan kelompok kontrol berdasarkan dari analisis Cohen's $d$. Ketiga aspek yang dianalisis pada perilaku fasilitator yaitu keselarasan peran, keselarasan kognitif dan penguasaan materi juga menunjukkan perbedaan yang tidak bermakna secara praktis yang dilihat dari nilai Cohens'd kurang dari 1.

\section{Pengaruh optimalisasi peran fasilitator terhadap motivasi intrinsik mahasiswa dalam diskusi kelompok}

Pada Tabel 3 dapat dilihat motivasi intrinsik mahasiswa secara umum tampak rata-rata total sebesar 5,08 setelah pelatihan, sedangkan 4,93 sebelum pelatihan menunjukkan perbedaan yang tidak bermakna secara praktis berdasarkan dari analisis Cohen's $d$. Keempat aspek yang dianalisis pada motivasi intrinsik mahasiwa menunjukkan bahwa aspek ketertarikan, usaha, nilai dan ketegangan tidak memiliki perbedaan yang bermakna secara praktis yang dilihat dari nilai Cohens'd kurang dari 1.

\footnotetext{
Hubungan peran fasilitator dengan keefektifan diskusi kelompok dan motivasi intrinsik mahasiswa

Berdasarkan hasil yang ditampilkan pada Tabel 4, tampak bahwa terdapat korelasi yang signifikan secara statistik, namun tidak secara praktis antara perilaku fasilitator dan efektifitas diskusi kelompok dan motivasi intrinsik mahasiswa. Dilihat dari Cohen's $d$, perilaku fasilitator memiliki efek sedang (moderate effect) terhadap efektifitas diskusi kelompok dan motivasi intrinsik mahasiswa.
} 
Tabel 1 Perbandingan rata-rata aspek-aspek keefektifan diskusi kelompok (Tutorial Group Effectiveness Instrument) sebelum dan setelah pelatihan fasilitator

\begin{tabular}{lccccc}
\hline Subskala & Pre & (SD) & Post & (SD) & Cohens'd \\
\hline Aspek kognitif & 3,83 & 0,19 & 3,76 & 0,14 & $-0,42$ \\
Aspek motivasi & 4,01 & 0,27 & 4,08 & 0,23 & 0,08 \\
Aspek demotivasi & 2,93 & 0,41 & 3,66 & 0,67 & 1,33 \\
Total rata-rata & 3,69 & 0,18 & 3,88 & 0,23 & 0,93 \\
\hline
\end{tabular}

Tabel 2 Perbandingan rata-rata aspek-aspek perilaku fasilitator (Tutor Behaviour Questionnaire) sebelum dan setelah pelatihan fasilitator

\begin{tabular}{lccccc}
\hline Subskala & Pre & (SD) & Post & (SD) & Cohens'd \\
\hline Keselarasan peran & 3,71 & 0,36 & 3,8 & 0,3 & 0,27 \\
Keselarasan kognitif & 3,6 & 0,27 & 3,74 & 0,31 & 0,49 \\
Penguasaan materi & 4,13 & 0,5 & 4,16 & 0,42 & 0,07 \\
Total rata-rata & 3,81 & 0,28 & 3,89 & 0,28 & 0,29 \\
\hline
\end{tabular}

Tabel 3 Perbandingan rata-rata aspek-aspek motivasi intrinsik mahasiswa (Intrinsic Motivation Inventory) sebelum dan setelah pelatihan fasilitator

\begin{tabular}{lccccc}
\hline Subskala & Pre & (SD) & Post & (SD) & Cohens'd \\
\hline Ketertarikan & 4,88 & 0,48 & 5,06 & 0,45 & 0,39 \\
Usaha & 4,87 & 0,54 & 4,97 & 0,52 & 0,19 \\
Nilai & 5,94 & 0,46 & 6,01 & 0,41 & 0,16 \\
Ketegangan & 3,99 & 0,64 & 4,3 & 0,59 & 0,51 \\
Total rata-rata & 4,93 & 0,39 & 5,08 & 0,38 & 0,39 \\
\hline
\end{tabular}

Tabel 4 Korelasi perilaku fasilitator dengan keefektifan diskusi kelompok dan motivasi intrinsik mahasiswa

\begin{tabular}{lcc}
\multirow{2}{*}{ Variabel } & \multicolumn{2}{c}{ Perilaku fasilitator } \\
\cline { 2 - 3 } & Koefisien korelasi & $p$ \\
\hline Efektivitas diskusi kelompok & 0,325 & 0,016 \\
Motivasi intrinsik & 0,373 & 0,005
\end{tabular}

\section{PEMBAHASAN}

\section{Pengaruh optimalisasi peran fasilitator terhadap keefektifan diskusi kelompok}

Pada penelitian ini didapatkan keefektifan diskusi kelompok yang meningkat walaupun tidak bermakna secara praktis. Diskusi kelompok yang efektif dipengaruhi oleh fasilitator, prior knowledge dan kualitas masalah. Peran fasilitator pada masing-masing aspek efektifitas diskusi kelompok diantaranya adalah pada aspek kognitif, fasilitator diharapkan mampu untuk mengarahkan kelompok diskusi untuk berinteraksi, berdiskusi, memberikan pendapat dan memberikan penjelasan satu sama lain. Proses kognitif ini diasumsikan mempunyai pengaruh yang positif terhadap pembelajaran mahasiswa. ${ }^{[8,9]}$ Pada aspek motivasi, fasilitator diharapkan mampu untuk mengatur kohesi dan semangat anggota kelompok. Aspek motivasi tersebut antara lain rasa tanggung jawab, kepekaan terhadap anggota lainnya, semangat untuk belajar mandiri dan komitmen untuk memajukan perkembangan kelompok. Dari aspek 
demotivasi fasilitator dipersepsikan mampu untuk memicu peserta diskusi untuk memberikan kontribusi dalam diskusi kelompok. Aspek demotivasi ini mengalami peningkatan yang signifikan dan bermakna secara praktis dan berperan terhadap peningkatan keefektifan diskusi kelompok pada penelitian ini. Hal ini berarti bahwa fasilitator mampu meningkatkan kontribusi masing-masing anggota kelompok, memotivasi mahasiswa untuk membagi informasi yang didapat saat diskusi, mencegah pengaruh negatif mahasiswa terhadap kontribusi mahasiswa lain, serta mengarahkan agar seluruh anggota ikut serta dalam menyelesaikan tugas kelompok. ${ }^{[10,11,12]}$

Berkurangnya faktor ketegangan pada mahasiswa saat berdiskusi juga mempengaruhi peningkatan sub demotivasi pada keefektifan diskusi kelompok. Hal ini ditunjukkan oleh hasil motivasi intrinsik mahasiswa yang tampak bahwa sub ketegangan memiliki skor Cohen's $d$ yang paling tinggi meskipun tidak bermakna secara praktis. Dengan berkurangnya ketegangan mahasiswa berupa perasaan cemas, gugup, tegang, tertekan saat diskusi akan memotivasi mahasiswa untuk lebih banyak berkontribusi dalam diskusi. Hal inilah yang dapat memperbaiki faktor sub demotivasi pada keefektifan diskusi kelompok. ${ }^{[12]}$

\section{Pengaruh optimalisasi peran fasilitator terhadap perilaku fasilitator dalam memfasilitasi diskusi kelompok}

Ketiga aspek yang dianalisis pada perilaku fasilitator yaitu keselarasan peran, keselarasan kognitif dan penguasaan materi menunjukkan perbedaan yang tidak bermakna secara praktis.

Keselarasan peran didefinisikan sebagai kesediaan fasilitator untuk menjadi "mahasiswa di antara mahasiswamahasiswa", yang artinya kesediaan untuk membangun hubungan informal dengan mahasiswa dan menunjukkan sikap perhatian dengan pribadi mahasiswa. Keselarasan kognitif didefinisikan sebagai kemampuan fasilitator untuk mengekspresi- kan penjelasan fasilitator dalam bahasa mahasiswa, menggunakan konsep-konsep yang mereka gunakan dan menjelaskan sesuatu dengan cara yang mudah dipahami mahasiswa. ${ }^{[3,14]}$ Moust (1995) menyatakan bahwa keselarasan kognitif juga diasumsikan sebagai kepekaan dari fasilitator mengenai kesulitan-kesulitan yang mungkin dihadapi oleh mahasiswa ketika bertemu dengan permasalahan atau materi yang terkait dengan permasalahan yang dibahas. ${ }^{[15]}$ Fasilitator akan mengetahui kapan harus melakukan intervensi dan apa yang dilakukan: bertanya untuk melakukan klarifikasi, memberikan contoh perbandingan, atau memberikan penjelasan singkat kepada mahasiswa. Fasilitator hanya dapat melakukan ini dengan baik jika mempunyai penguasaan materi yang relevan dan mempunyai perhatian terhadap kehidupan mahasiswa dan proses belajarnya. Tanpa penguasaan materi, fasilitator akan sulit mengikuti garis pemahaman mahasiswa dan tanpa mempunyai perhatian terhadap mahasiswa dan proses belajarnya fasilitator tidak akan mempunyai dorongan untuk memahami kesulitan yang dihadapi mahasiswa dalam pembelajarannya. Oleh karena itu, baik penguasaan materi dan kualitas interpersonal dari fasilitator diperlukan untuk timbulnya keselarasan kognitif.

Fasilitator yang efektif harus memiliki dua kemampuan dasar yaitu kompetensi, wawasan pada konten pembelajaran serta mampu mengendalikan kelompok diskusi. Kedua hal ini memerlukan pelatihan terus menerus (kontinyu) sehingga dapat dipergunakan semestinya demi kemajuan kelompok diskusi. [16] Karakter maupun perilaku dibentuk dalam waktu yang tidak singkat dengan paparan masalah ataupun pemicu yang terus menerus. Penelitian ini mendapatkan hasil bahwa pelatihan tidak memberikan efek yang bermakna secara praktis pada perilaku fasilitator, yang kemungkinan disebabkan oleh lama waktu pelatihan yang singkat (4 jam), kehadiran fasilitator tidak penuh saat pelatihan serta 
role play dengan mahasiswa simulasi hanya satu kali. Sehingga kegiatan pelatihan ini belum mampu untuk mengubah karakter maupun perilaku fasilitator. Faktor lain yang berpengaruh pada keefektifan selain faktor dari perilaku fasilitator adalah kualitas masalah dan prior knowledge dari mahasiswa.

\section{Pengaruh optimalisasi peran fasilitator terhadap motivasi intrinsik mahasiswa dalam diskusi kelompok}

Keempat aspek yang dianalisis pada motivasi intrinsik mahasiwa menunjukkan bahwa aspek ketertarikan, usaha, nilai dan ketegangan tidak memiliki perbedaan yang bermakna secara praktis.

Menurut Ryan \& Deci (2000), motivasi merupakan sesuatu yang berkelanjutan dengan motivasi intrinsik pada salah satu ujung spektrum dan amotivation (kurang atau tidak adanya motivasi) pada sisi yang lainnya. Motivasi intrinsik membuat seseorang melakukan tindakan karena ketertarikan personal atau kesenangan. Motivasi ekstrinsik membuat seseorang melakukan aktivitas dengan tujuan yang dapat dipisahkan, seperti mendapatkan had$\mathrm{iah} /$ pujian atau menghindari kegagalan. Teori motivasi juga mempostulatkan bahwa motivasi dapat mengalami pertukaran dari ekstrinsik ke intrinsik dan sebaliknya tergantung dari perasaan autonomy, competence dan relatedness dari pengalamannya mahasiswa terhadap pengajarannya. ${ }^{[17]}$

Penelitian dari Artino, La Rochelle, \& Durning (2010) menyimpulkan bahwa kepercayaan motivasi (motivational beliefs) seperti keyakinan diri (self efficacy) dan penilaian terhadap tugas (task value) merupakan kontributor yang penting terhadap pencapaian akademik mahasiswa. Perasaanperasaan yang terlibat dalam pencapaian tersebut seperti kesenangan, kecemasan dan kebosanan dalam melakukan tugas tertentu juga terkait dengan pencapaian akademik mahasiswa. ${ }^{[18]}$

Pada penelitian ini didapatkan bahwa perilaku fasilitator belum mampu memberikan efek yang bermakna secara praktis terhadap motivasi intrinsik dari mahasiswa.
Hal ini kemungkinan disebabkan oleh: 1) Durasi penelitian yang relatif pendek (empat minggu), sehingga fasilitator belum mampu untuk menumbuhkan dan membawa motivasi mahasiswa ke arah motivasi intrinsik, 2) mahasiswa kemungkinan masih memandang kegiatan ini sebagai beban tambahan dan kewajiban yang harus dilakukan sehingga timbul ketegangan serta kebosanan dalam mengikuti penelitian.

\section{Hubungan peran fasilitator dengan keefektifan diskusi kelompok dan motivasi intrinsik mahasiswa}

Pada penelitian ini didapatkan korelasi yang signifikan secara statistik, namun tidak bermakna secara praktis antara perilaku fasilitator dan efektifitas diskusi kelompok dan motivasi intrinsik mahasiswa. Selain itu efektivitas diskusi kelompok mempunyai hubungan yang setara bila dibandingkan dengan motivasi intrinsik. Teori konseptual dari Moust yang menyatakan perilaku fasilitator akan mempungaruhi efektivitas diskusi kelompok yang selanjutnya akan mempengaruhi motivasi intrinsik mahasiswa terhadap subjek yang dipelajari (peran serta dalam diskusi kelompok) yang akhirnya akan mempengaruhi pencapaian akademik mahasiswa. ${ }^{[15]}$ Dalam hubungannya dengan perilaku fasilitator, ternyata efektivitas diskusi kelompok mempunyai hubungan yang setara bila dibandingkan dengan motivasi intrinsik. Penelitian ini selaras dengan konsep Moust, perilaku fasilitator akan mempengaruhi diskusi kelompok yang selanjutnya mempengaruhi motivasi intrinsik mahasiswa.

Hasil penelitian dari Yani Istadi menunjukkan kinerja fasilitator merupakan salah satu penentu efektifitas diskusi kelompok, selain kualitas kasus/masalah, dimensi kepercayaan hubungan antar anggota dalam kelompok, dimensi perilaku belajar kelompok, dan motivasi. Semakin tinggi kinerja fasilitator maka akan semakin tinggi keefektifan diskusi kelompok tersebut, serta kinerja fasilitator merupakan prediktor bagi keefektifan 
diskusi kelompok. $^{[7]}$

Williams dan Paltridge

mengemukakan dari beberapa penelitian menunjukkan bahwa fasilitator yang efektif adalah fasilitator yang mengetahui topik masalah dan mampu mentransfer informasi sehingga mahasiswa dapat memahami secara keseluruhan; mampu mengetahui waktu untuk intervensi pada pembelajaran mahasiswa; serta memotivasi mahasiswa untuk lebih memahami informasi daripada hanya mengumpulkannya. Institusi pendidikan sebaiknya memandang program pengembangan fasilitator sebagai investasi jangka panjang dalam pembelajaran siswa, karena perubahan yang signifikan hanya dapat dilakukan secara kontinyu dan berkelanjutan $^{[19]}$

\section{SIMPULAN}

Hasil penelitian ini menunjukkan bahwa pelatihan fasilitator pada blok memiliki arah yang positif terhadap keefektifan diskusi kelompok, tetapi masih perlu ditingkatkan baik kualitas, intensitas maupun keberlanjutannya. Serta terdapat hubungan antara peran fasilitator dengan keefektifan diskusi kelompok dan motivasi intrinsik mahasiswa.

\section{UCAPAN TERIMA KASIH}

Penulis mengucapkan terima kasih kepada Program Hibah Kompetensi Peningkatan Kualitas Pendidikan Dokter (PHKPKPD), proyek HPEQ Direktorat Pembelajaran dan Kemahasiswaan, Direktorat Jendral Pendidikan Tinggi, Kementrian Pendidikan dan Kebudayaan Republik Indonesia atas dana penelitian yang diberikan pada penelitian ini.

\section{DAFTAR PUSTAKA}

1. Abbat, F.R. (1992). Teaching for Better Learning, A Guide for Teachers of Primary Health Care. $2^{\text {nd }}$ ed. Geneva: World Health Organization.

2. Dent, J. A., Ronald M. H., (2003). A Practical Guide for Medical Teachers. London: Churchill Livingstone
3. Hamzah, B.U. (2008). Model Pembelajaran Menciptakan Proses Belajar Mengajar Yang Kreatif dan Efektif. Jakarta: Bumi Aksara

4. Sudjana, N. (2000). Dasar-Dasar Proses Belajar Mengajar. Bandung: Sinar Baru Algesindo

5. Crosby, J., 1996. Learning in small groups. Med Teach.;18(3):189-202.

6. Faizin, 2009. Efektifitas Diskusi dalam Meningkatkan Kemampuan Berpikir dan Berpendapat. Studi Kasus Pada Pembelajaran Civic; 18 (1): 2085-3033.

7. Istadi, Y., Harsono, Prabandari, Y.S., 2012. Faktor-faktor yang dianggap sebagai prediktor terhadap keefektfan kelompok tutorial problem based learning (PBL). Jurnal Pendidikan Kedokteran Indonesia; 2(1): 59-67. Slavin, R.E., 1996. Research on cooperative learning and achievement: What we know, what we need to know. Contemporary Educational Psychology;21: 43-69.

8. Pariartha, I.M., Sanusi, R., Hadianto, T., 2015. Perbedaan efektivitas diskusi kelompok, motivasi intrinsik dan nilai modul dari mahasiswa yang difasilitasi dosen dan tutor sebaya. Jurnal Pendidikan Kedokteran Indonesia; 3: 100-107.

9. Azer, S.A., 2009. Interactions between students and tutor in problem-based learning: the significance of deep learning. Kaohsiung J Med Sci;25:240-9.

10. Chan, L.C., 2008. The role of PBL tutor: a personal persepective. Kaohsiung J Med Sci;24: S34-8.

11. Sianipar, I.M.G., Hilmanto, D., Siregar, I.M.P., Husin, F., Sutedja, E., Sukandar, H., 2016. Hubungan kinerja tutor dan kualitas kasus skenario terhadap keefektifan kelompok pada metode belajar problem based learning. IJEMC;3:17.

12. Schmidt, H.G., Moust, J.H.C., 1995. What makes a tutor effective? A structural-equations modeling 
approach to learning in problembased learning curricula. Academic Medicine; 70(8):708-714.

13. Schmidt, H.G., Moust, J.H.C., 2000. Factors affecting small-group tutorial learning: A review of research. In: Evensen DH, Hmelo CE, editors. Problem-based learning: a research perspective on learning interactions. New York: Lawrence Erlbaum;19-52.

14. Moust, J.H.C., Schmidt, H.G., 1995. Facillitating small-group learning: a comparison of student and staff tutor's behavior. Instruction Science; 22:287-301.

15. Isa, N.J.M., Jusoh, A.J., Razali, M.M.S.M., 2015. Problem-based learning: mandatory personal qualities of effective facilitators. IJLTER;13:88-96.

16. Ryan, R.M., Deci, E.L., 2000. Selfdetermination theory and the facilitation of intrinsic motivation, social development, and well being. American Psychologist; 55(1): 68-78.

17. Artino, A.R., La Rochelle, J.S., Durning, S.J., 2010. Second-year medical students' motivational beliefs, emotions, and achievement. Medical Education; 44: 1203-1212.

18. Williams, J.C. and Paltridge, D.J., 2016. What we think we know about the tutor in problem-based learning. Health Professions Education;3:2631. 